\title{
RESPONSE TO MERCURIAL DIURETICS DURING ALKALOSIS: A COMPARISON OF ACUTE METABOLIC AND CHRONIC HYPOKALEMIC ALKALOSIS IN THE DOG ${ }^{1}$
}

\author{
By GILBERT H. MUDGE ${ }^{2}$ AND BYRON HARDIN WITH THE TECHNICAL ASSISTANCE OF \\ THEODORA J. LANNON
}

\author{
(From the Department of Medicine, College of Physicians and Surgeons, Columbia University, \\ and the Presbyterian Hospital, New York, N. Y.)
}

(Submitted for publication September 12, 1955 ; accepted October 10, 1955)

A relationship between the action of mercurial diuretics and acid-base metabolism has been established for many years. Diuresis may be augmented by the administration of acidifying salts such as ammonium chloride (1), and may be decreased or even totally inhibited by alkalinizing agents $(2,3)$. Although a variety of clinical and experimental studies suggest that the mercurials act by decreasing the tubular reabsorption of the chloride ion (3-7), it is not clear exactly why this action of the drug is so susceptible to changes in acid-base balance.

Recent reviews have emphasized the role of glomerular factors in determining the response to mercurials. Potentiation by ammonium chloride has been attributed to an increase in the filtered chloride load, rather than to changes in the $\mathrm{pH}$ of the serum or of the urine (3). Conversely, it has been proposed that the refractoriness seen in metabolic alkalosis is due to a decrease in the amount of chloride filtered at the glomerulus (7). In addition, when the level of serum chloride is kept constant but the filtration rate is changed, the diuretic effect of the mercurials varies directly with the filtered chloride load (8).

It had previously been postulated that the $\mathrm{pH}$ of the tubular urine, or of the surrounding cells, might directly modify the dissociation of the mercurial and hence determine the extent to which mercury became affixed to the tubule (9). Although changes in the reactivity of the tubule to mercury have not been directly demonstrated, this possibility continues to be suggested by several observations which can not be explained solely

1 This study was supported in part by a grant from the Rockefeller Foundation to Dr. J. V. Taggart.

2 Present address: Department of Pharmacology and Experimental Therapeutics, The Johns Hopkins University School of Medicine, Baltimore, Maryland. by glomerular factors (i.e., the filtered chloride load). Hilton (10) showed that the potentiation by ammonium chloride persisted in long term experiments after the elevated level of chloride in the serum had returned to normal. Since filtration rates were not measured, an increase in the amount of chloride filtered could not be excluded. However, it is clear that potentiation was not due to hyperchloremia alone. More striking discrepancies between the chloride load and the effectiveness of mercurials have been observed during acute hypochloremia. The chloruretic action of mercury may be completely abolished by infusions of sodium bicarbonate $(3,11)$ but not by infusions of sodium nitrate (6) which produce a comparable depression of the serum chloride level.

The acute administration of either acidifying or alkalinizing salts changes the $\mathrm{pH}$ of the calculated intracellular space in the same direction as it does that of the plasma (12). Presumably, the cells of the renal tubule respond in a similar manner. Thus, when large volumes of bicarbonate are infused, the resultant hypochloremia is accompanied by an increase in the $\mathrm{pH}$ of the extracellular fluid, of the tubular urine, and of the cells of the renal tubule. If the overall effect of the mercurials were dependent not only on the amount of chloride filtered but also on the $\mathrm{pH}$ of the tubules, these separate factors might not readily be dissociated by acute experiments with infusions of this type.

A possible method for elucidating the role of tubular $\mathrm{pH}$ was suggested by recent studies on the acid-base disturbance associated with potassium depletion. This is characterized by an extracellular alkalosis with hypochloremia, but the intracellular fluid becomes more acid. These changes have been demonstrated for skeletal muscle by several different techniques $(13,14)$ and for the renal epithelium both by indirect methods 
in the intact animal $(15,16)$ and by direct tissue analysis under in vitro conditions (17).

The present experiments were therefore undertaken to compare the effect of organic mercurial diuretics during acute metabolic alkalosis (extracellular and intracellular alkalosis) with their effect during potassium depletion (extracellular alkalosis and intracellular acidosis). The results clearly indicate that the diuretic response is not solely determined by the filtered chloride load, and, therefore, that tubular factors must play an important role.

\section{METHODS}

The effect of meralluride on electrolyte excretion was determined by clearance techniques in two trained female dogs which were depleted of potassium by the combination of a synthetic low potassium diet and the daily subcutaneous injection of $10 \mathrm{mg}$. of desoxycorticosterone acetate (DCA). Control studies in the pre-depletion period were made in $\operatorname{dog} B$ while on a stock diet of Kasco Dog Ration and in $\operatorname{dog} \mathrm{W}$ while on the synthetic diet supplemented by $50 \mathrm{mEq}$. $\mathrm{KCl}$ per day. Venous blood was taken 2 to 3 times per week for estimation of plasma electrolytes. When the syndrome of alkalosis due to potassium depletion was fully developed, the effect of meralluride was again determined. The animals were then placed on a diet of raw hamburger and were given $20 \mathrm{mEq}$. per $\mathrm{L}$. of $\mathrm{KCl}$ as drinking water; the administration of DCA was continued. The effects of meralluride were again determined after potassium repletion.

After the first period of potassium depletion dog B was placed on a stock diet for two months, and was then depleted again. In the second experiment, meralluride was given every two to three days while 1) on the synthetic diet with supplementary potassium, 2) on the same diet without potassium and 3) on the low potassium diet plus $20 \mathrm{mg}$. DCA per day. Electrolyte excretion was determined in daily specimens rather than for shorter collection periods.

The animals were kept in metabolism cages and the voided urine was collected daily. The volume, $\mathrm{pH}$, specific gravity, and the concentrations of sodium, potassium, and chloride in the urine were determined each day. The feces were not measured. The daily balance was estimated as the difference between dietary intake (corrected for uneaten residues) and urinary excretion. Appropriate corrections were also made for the amount of electrolyte infused and excreted during the clearance studies. Water intake was not measured except during the period of potassium repletion when the $\mathrm{KCl}$ in the water was added to the calculated intake. No correction was made for the electrolytes removed in the blood samples. In calculating the cumulative balance, zero balance was assumed for the day on which the low potassium diet was started.

The electrolyte content of each diet was determined by analysis of nitric acid digests. The synthetic diet was (by weight) : acid-washed casein 20 per cent, sucrose 44 per cent, hydrogenated vegetable fat (Crisco) 35 per cent, and Ruffex, 0.5 to 1.0 per cent. To $100 \mathrm{gm}$. of this diet were added $3.5 \mathrm{gm}$. of a supplementary salt mixture consisting of calcium, phosphate, magnesium, iron and trace elements (cf. 13). Vitamins were also added in adequate amounts. Dog B received $200 \mathrm{gm}$. and dog W $250 \mathrm{gm}$. of the diet per day. By analysis of different lots, the daily amount of electrolyte in the diet was less than $0.2 \mathrm{mEq}$. of potassium, less than $0.6 \mathrm{mEq}$. of sodium, and from 6 to $9 \mathrm{mEq}$. of chloride. To the first diet of dog $\mathrm{B}$ were added weighed quantities of $\mathrm{NaHCO}_{3}$ and $\mathrm{NaCl}$. Minor alterations were made during the course of the experiment, but the average intake was 100 $\mathrm{mEq}$. of sodium and $50 \mathrm{mEq}$. each of chloride and bicarbonate per day. Dog W received $50 \mathrm{mEq}$. of $\mathrm{KCl}$ and $50 \mathrm{mEq}$. mono-sodium glutamate during the control period, and an equivalent amount of $\mathrm{NaCl}$ was substituted for the $\mathrm{KCl}$ during the depletion period. The glutamate was added in an attempt to make the diet more appetizing, but the results were equivocal. The second experiment on $\operatorname{dog} \mathrm{B}$ was with a similar diet, i.e., with glutamate added. In the first experiment, dog B had received an equivalent amount of sodium bicarbonate. The changes in electrolyte metabolism and the response to meralluride were the same in both instances.

Renal clearances were performed with standard techniques using the exogenous creatinine clearance as a measure of the glomerular filtration rate. The animals were studied in the fasting state but had been allowed free access to water. After the priming infusion, onehalf hour was allowed for equilibration and then two control periods were taken. One ml. of meralluride (Mercuhydrin ${ }^{(}$, Lakeside Labs., Milwaukee; 39 mg. mercury per ml.) was injected intravenously during the course of five minutes. Observations were continued for five to six more clearance periods.

Blood was taken from the jugular vein in an heparinized oiled syringe. An aliquot was kept anaerobically under mineral oil for carbon dioxide determination; the blood was centrifuged promptly and the plasma separated. In experiments 5 and 6 , urine was collected under oil without bladder irrigation, but in all other experiments the bladder was washed with $15 \mathrm{ml}$. distilled water at the end of each collection period. The failure to employ an anaerobic technique for the collection of urine introduced minor errors into the determination of carbon dioxide in the urine, but these were so small that this procedure was adopted since it assured more complete emptying of the bladder.

Plasma creatinine was determined on trichloracetic acid filtrates by the alkaline-picrate method; sodium and potassium by internal standard flame photometry; plasma carbon dioxide by the manometric method of Van Slyke; ${ }^{8}$

\footnotetext{
8 The plasma bicarbonate concentration was calculated from the total $\mathrm{CO}_{2}$ content assuming a constant $\mathrm{pCO}_{2}$, except in the experiment in which plasma $\mathrm{pH}$ was directly determined.
} 
urine carbon dioxide by either the volumetric or manometric method of Van Slyke; and chloride (first experiment $\operatorname{dog}$ B) by the method of Schales and Schales (18), and in the other experiments by a modified Volhard procedure.

\section{RESULTS}

The experimental plan and a summary of the results are shown in Table $I$. The effect of meralluride on electrolyte excretion was measured in a total of twelve clearance experiments while on the control diet, during potassium depletion, and after the potassium deficit had been corrected.

\section{General course of potassium depletion}

Each dog ate all of the synthetic diet and maintained body weight for 3 to 4 weeks, but thereafter food was gradually refused. The development of potassium depletion was associated with episodes of muscular weakness and paralysis which became progressively more severe. Both the anorexia and the asthenia promptly disappeared when the animals were potassium repleted. During the period of the low potassium diet, there was marked polydipsia and polyuria and the urine was

TABLE I

Summary of balance data and clearances showing chloruretic effect of meralluride during different types of alkalosis

\begin{tabular}{|c|c|c|c|c|c|c|c|c|c|c|c|c|c|}
\hline \multirow[b]{2}{*}{ Day } & \multirow[b]{2}{*}{ Wt. } & \multirow[b]{2}{*}{ Exp. } & \multirow[b]{2}{*}{ Remarks } & \multicolumn{3}{|c|}{ Cumulative balance } & \multirow[b]{2}{*}{ Infusion* } & \multicolumn{4}{|c|}{ Plasma† } & \multirow[b]{2}{*}{ GFR } & \multirow{2}{*}{$\begin{array}{l}\text { Change in } \\
\text { chloride } \\
\text { excretions }\end{array}$} \\
\hline & & & & $\mathrm{Na}$ & $\mathbf{K}$ & $\mathrm{Cl}$ & & $\mathrm{Na}$ & $\mathbf{K}$ & $\mathrm{HCO}_{3}$ & $\mathrm{Cl}$ & & \\
\hline & $K_{g}$ & & & & $m E q$. & & $m E q . / L$ & & $m E$ & $q . / L$ & & $m l . / m i n$. & $m E q$. \\
\hline & \multicolumn{13}{|c|}{ DOG B } \\
\hline-6 & 14.6 & 1 & Normal diet & - & - & - & None & 145 & 4.4 & 23.5 & 115 & 47 & +51 \\
\hline-3 & 14.6 & 2 & Normal diet & - & - & - & $\mathrm{NaHCO}_{3}, 150$ & - & - & 24.5 & 117 & & \\
\hline \multirow{3}{*}{$\begin{array}{r}0 \\
7 \\
15 \\
25 \\
26 \\
35\end{array}$} & 14.4 & & \multirow{3}{*}{\multicolumn{5}{|c|}{ 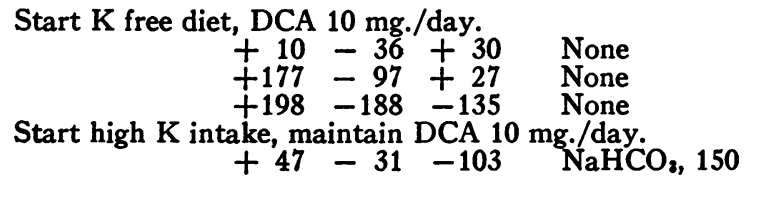 }} & 141 & & & & Ji & \\
\hline & $\begin{array}{l}14.6 \\
15.0 \\
14.4\end{array}$ & $\begin{array}{l}3 \\
4 \\
5\end{array}$ & & & & & & $\begin{array}{l}148 \\
144 \\
148\end{array}$ & $\begin{array}{l}3.4 \\
2.7 \\
2.3\end{array}$ & $\begin{array}{l}26.0 \\
25.6 \\
33.1\end{array}$ & $\begin{array}{l}114 \\
112 \\
105\end{array}$ & $\begin{array}{l}44 \\
45 \\
45\end{array}$ & $\begin{array}{l}+57 \\
+37 \\
+47\end{array}$ \\
\hline & 13.6 & 6 & & & & & & $\begin{array}{l}144 \\
149\end{array}$ & $\begin{array}{l}4.3 \\
2.8\end{array}$ & $\begin{array}{l}23.6 \\
33.5\end{array}$ & $\begin{array}{l}112 \\
105\end{array}$ & 49 & -3 \\
\hline & \multicolumn{13}{|c|}{ DOG W } \\
\hline-7 & 17.7 & 7 & Normal diet & - & 一 & - & $\mathrm{NaHCO}_{3}, 150$ & $\begin{array}{l}149 \\
140\end{array}$ & $\begin{array}{l}4.3 \\
3.0\end{array}$ & $\begin{array}{l}23.2 \\
33.0\end{array}$ & $\begin{array}{l}110 \\
100\end{array}$ & 53 & +13 \\
\hline-3 & 17.3 & 8 & & 一 & 一 & - & $\begin{array}{l}\mathrm{NaCl}, 120 \\
\mathrm{NaHCO}_{3}, 25\end{array}$ & $\begin{array}{l}149 \\
148\end{array}$ & $\begin{array}{l}4.3 \\
3.4\end{array}$ & $\begin{array}{l}23.2 \\
23.2\end{array}$ & $\begin{array}{l}111 \\
109\end{array}$ & 63 & +41 \\
\hline $\begin{array}{r}0 \\
23\end{array}$ & 16.8 & 9 & Start $\mathrm{K}$ free & $\begin{array}{l}\text { t, DCA } \\
+299\end{array}$ & $\begin{array}{l}10 \mathrm{mg} . \\
-220\end{array}$ & $\begin{array}{l}\text { /day. } \\
+107\end{array}$ & $\begin{array}{l}\mathrm{NaCl}, 45 \\
\mathrm{NaHCO}_{3}, 100\end{array}$ & $\begin{array}{l}148 \\
154\end{array}$ & $\begin{array}{l}3.3 \\
2.5\end{array}$ & $\begin{array}{l}30.6 \\
38.1\end{array}$ & $\begin{array}{l}100 \\
101\end{array}$ & 31 & -3 \\
\hline 30 & 15.0 & 10 & & +457 & -271 & +171 & $\begin{array}{l}\mathrm{NaCl}, 90 \\
\mathrm{NaHCOO}, 31 \\
\mathrm{KCL}, 10\end{array}$ & $\begin{array}{l}137 \\
139\end{array}$ & $\begin{array}{l}2.1 \\
1.9\end{array}$ & $\begin{array}{l}29.5 \\
31.9\end{array}$ & $\begin{array}{l}93 \\
95\end{array}$ & 57 & +80 \\
\hline $\begin{array}{l}31 \\
39\end{array}$ & 15.5 & 11 & Start high K & $\begin{array}{l}\text { ake, } m \\
\perp 484\end{array}$ & $\begin{array}{l}\text { intain } \\
-69\end{array}$ & $\begin{array}{c}\text { DCA } 10 \\
+328\end{array}$ & $\begin{array}{l}\mathrm{ng} \cdot / \mathrm{day} . \\
\mathrm{NaHCO} \\
3\end{array}$ & $\begin{array}{l}151 \\
152\end{array}$ & $\begin{array}{l}3.2 \\
2.5\end{array}$ & $\begin{array}{l}24.9 \\
35.9\end{array}$ & $\begin{array}{l}110 \\
100\end{array}$ & 60 & +5 \\
\hline 49 & 15.9 & 12 & & +557 & -11 & +403 & $\begin{array}{l}\mathrm{NaCl}, 120 \\
\mathrm{NaHCO}_{3}, 25\end{array}$ & $\begin{array}{l}150 \\
150\end{array}$ & $\begin{array}{l}3.0 \\
2.5\end{array}$ & $\begin{array}{l}23.3 \\
24.1\end{array}$ & $\begin{array}{l}111 \\
112\end{array}$ & 73 & +49 \\
\hline
\end{tabular}

* Infusions contained creatinine in addition to the components indicated and consisted of 600 and $425 \mathrm{ml}$. priming for experiments 2 and 6 , and between 500 and $550 \mathrm{ml}$. priming for experiments $7-12$; sustaining infusions were about $4 \mathrm{ml}$. per min., except experiment $6(2 \mathrm{ml}$. per min.). When no infusion is indicated, dog received only 3.5 per cent creatinine at less than $1 \mathrm{ml}$. per min.

$t$ Values for plasma electrolytes (when given on single line) are averages of two periods before and two periods after administration of meralluride. When plasma values are given on two lines, the upper refers to the plasma level before the indicated infusion, and the lower refers to the average during the experiment, as calculated above.

‡ Glomerular filtration rate (GFR) is average of two periods before and three periods after administration of meralluride.

Change in urinary excretion of chloride is calculated as the amount of chloride excreted during 100 mins. after injection of meralluride corrected for the rate of chloride excretion during the two control periods before meralluride.

$\| \mathrm{KCl}$ added to infusion of Exp. 10 in effort to prevent further depression of plasma $\mathrm{K}$ by dilution. 
consistently acid (about $\mathrm{pH}$ 6). When the potassium deficit was corrected, even though the administration of DCA was continued, there was a significant reduction in daily urine volume with a rise in the specific gravity and $\mathrm{pH}$ of the urine. Although the findings suggest a direct effect of potassium on the capacity of the kidney to excrete a concentrated urine, further studies seem warranted to define more accurately the relative roles of electrolyte imbalance and steroid administration in the pathogenesis of this "diabetes-insipidus" syndrome (cf. 19, 20).

The concentrations of electrolytes in the plasma changed in accordance with the pattern that has been previously described for chronic potassium depletion (21). The plasma bicarbonate rose about $10 \mathrm{mEq}$. per $\mathrm{L}$. and the chloride fell an equivalent amount. No consistent changes in the concentration of sodium were noted. The plasma potassium fell and remained in the region of 2 to $2.5 \mathrm{mEq}$. per $\mathrm{L}$. In $\operatorname{dog} \mathrm{B}$ at the height of potassium depletion (Exp. No. 5), the venous blood $\mathrm{pH}$ was 7.47 and the $\mathrm{pCO}_{2}$ was within normal limits. This is in agreement with the extensive studies of Roberts, Randall, Sanders, and Hood (16) who found no change in $\mathrm{PCO}_{2}$ during hypokalemic alkalosis. When the potassium intake was increased, the serum concentrations of bicarbonate, chloride and potassium were quickly restored towards normal.

Although the cumulative balance data (Table I) clearly demonstrate the development of negative potassium and positive sodium balances, it is probable that the values are subject to systematic errors. The careful studies of Howell and Davis (22) showed that large amounts of potassium were excreted in the feces of the dog given DCA; there was a significant fecal loss of sodium but this was less influenced by the steroid. In the present studies, fecal losses were not measured, nor was the nitrogen balance determined. These factors, combined with the inevitable losses in the metabolism cage, would indicate that the cumulative balances reported here are falsely high in a positive direction. However, it is probably of significance that the positive sodium balance was consistently much greater than the chloride balance. This suggests the migration of sodium to an intracellular site in exchange for potassium but further documentation by detailed calculations is not warranted by the present data. However, such intracellular changes have been demonstrated by tissue analyses in the dog after the production of an extracellular alkalosis by an experimental regimen similar to that employed here (23).

\section{Effect of meralluride}

During each clearance experiment, dog B received only small infusions of creatinine except when acute alkalosis was produced by the intravenous administration of large volumes of $0.15 \mathrm{~N}$ $\mathrm{NaHCO}_{3}$. Since this introduced a possibly undesirable variation in technique, the clearance studies on the second dog (W) were all carried out with infusions of similar volume but of different composition. The response to the mercurial was qualitatively the same in both dogs; the greater chloruretic effect in dog $\mathrm{W}$ is perhaps related to the increase in extracellular fluid volume which resulted from the infusion ( $c f .24)$.

The effect of alterations in acid-base metabolism on the response to meralluride was the same in both dogs. When an acute alkalosis was produced during the period of the normal diet, the animal became refractory to the mercurial. In contrast, a prompt diuresis of sodium, chloride and water was obtained when meralluride was administered during chronic hypokalemic alkalosis. ${ }^{4}$ In the two courses of potassium depletion in $\operatorname{dog} B$ and in the single one in $\operatorname{dog} \mathrm{W}$, there was a significant chloruresis each of the eight times that meralluride was given after the animals had become alkalotic, i.e., when the plasma bicarbonate was higher than $30 \mathrm{mEq}$. per L. and the plasma chloride less than $105 \mathrm{mEq}$. per L. The data of Figures 1 and 2 suggest that, despite the hypochloremia, the diuretic effect of the mercurial was greater and appeared sooner during the stage of potassium depletion than on the control diet. After the po-

4 It is recognized that the term hypokalemic alkalosis is somewhat of a misnomer since it defines the disturbance in acid-base metabolism in terms of the plasma level of potassium. Many studies have shown that the persistent extracellular alkalosis is primarily the result of the intracellular potassium deficit. In the present experiments, during the acute alkalosis resulting from sodium bicarbonate infusions, there was a fall in plasma potassium to about the same levels as seen during chronic potassium depletion. These experiments illustrate the failure of the plasma potassium level to serve as an accurate index of the intracellular balance. 


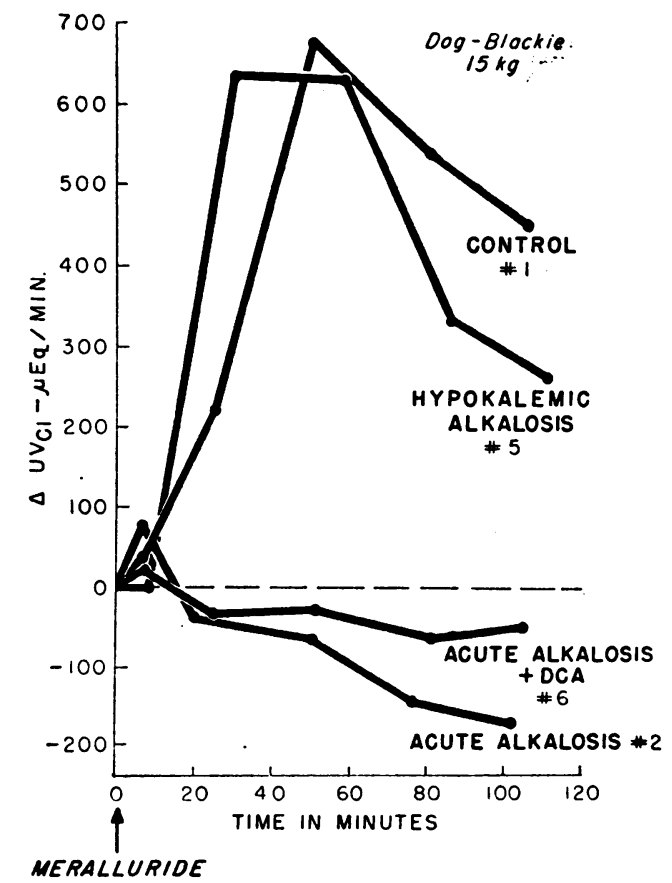

Fig. 1. Effect of Meralluride on Chloride ExcreTION-DOG B

Mid-point of each collection period is indicated. Change in chloride excretion ( $\triangle \mathrm{UVCl}$ ) is corrected for the rate observed during the two control periods before meralluride. For members identifying individual experiments, see Table I.

tassium balance had been restored towards normal and while the administration of DCA was continued, the production of an acute alkalosis was again associated with refractoriness to the mercurial, cf. Exps. 6 and 11 of Tables II and III. ${ }^{5}$ This indicates that the steroid was not directly responsible for the effectiveness of the mercurial during the period of potassium depletion.

The experiments were designed in an attempt to achieve the same levels of plasma bicarbonate and chloride during acute alkalosis as were obtained during the period of alkalosis due to potassium depletion. As indicated in the tables, the plasma levels were similar under these two conditions, and the marked difference in the chloruretic response cannot be attributed to minor differences in plasma electrolyte concentrations. Indeed, the

5 During acute alkalosis, an increased rate of chloride excretion was noted before the mercury was administered. These changes are similar to those previously described for experiments employing large infusions of sodium bicarbonate (25). maximal chloruresis was obtained with the lowest plasma chloride (Exp. No. 10). Similarly, there were only minor fluctuations in the glomerular filtration rate and they bore no relationship to the effectiveness of the diuretic. A possible exception to this is seen in Experiment No. 9, in which the mercurial was given after an acute alkalosis had been superimposed on the alkalosis due to potassium depletion. There was no chloruresis, and this might be attributed either to the lowered filtration rate or to the acute alkalosis per se. In experiment No. 10, the filtration rate fell immediately after the period of peak urine flow ( $c f$. Table III). This probably represents a hemodynamic response to the sudden dehydration caused by the exceptionally large diuresis.

The results of the second experiment on dog B are given in Figure 3 and demonstrate the persistent chloruretic effect of meralluride during the hypochloremia of potassium depletion. Although a transient period of refractoriness may be sug-

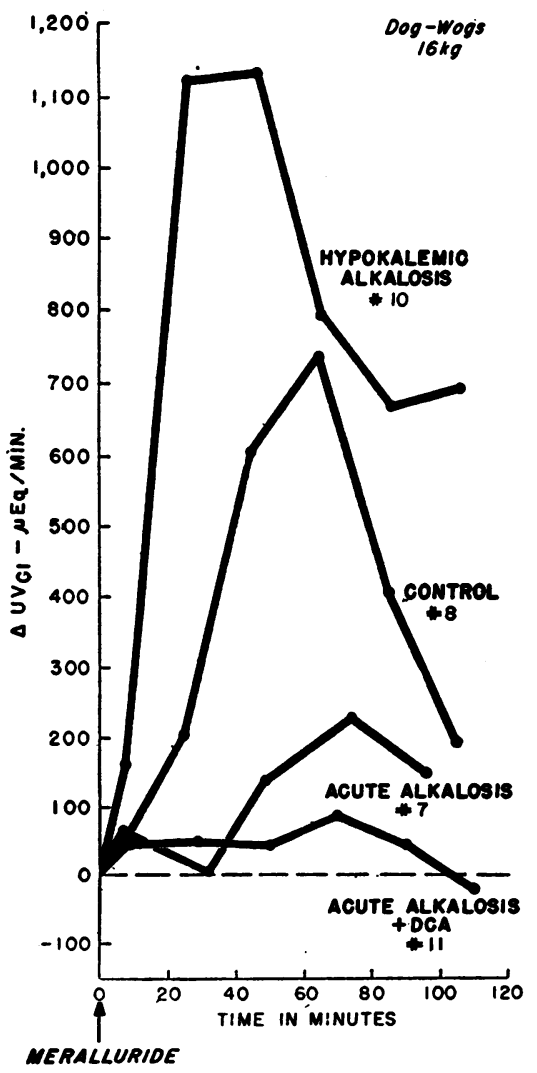

Fig. 2. Effect of Meralluride on Chloride ExcreTION-DoG W 
TABLE II

Protocols showing effect of meralluride on electrolyte excretion during alkalosis of potassium depletion and during acute metabolic alkalosis-Dog B

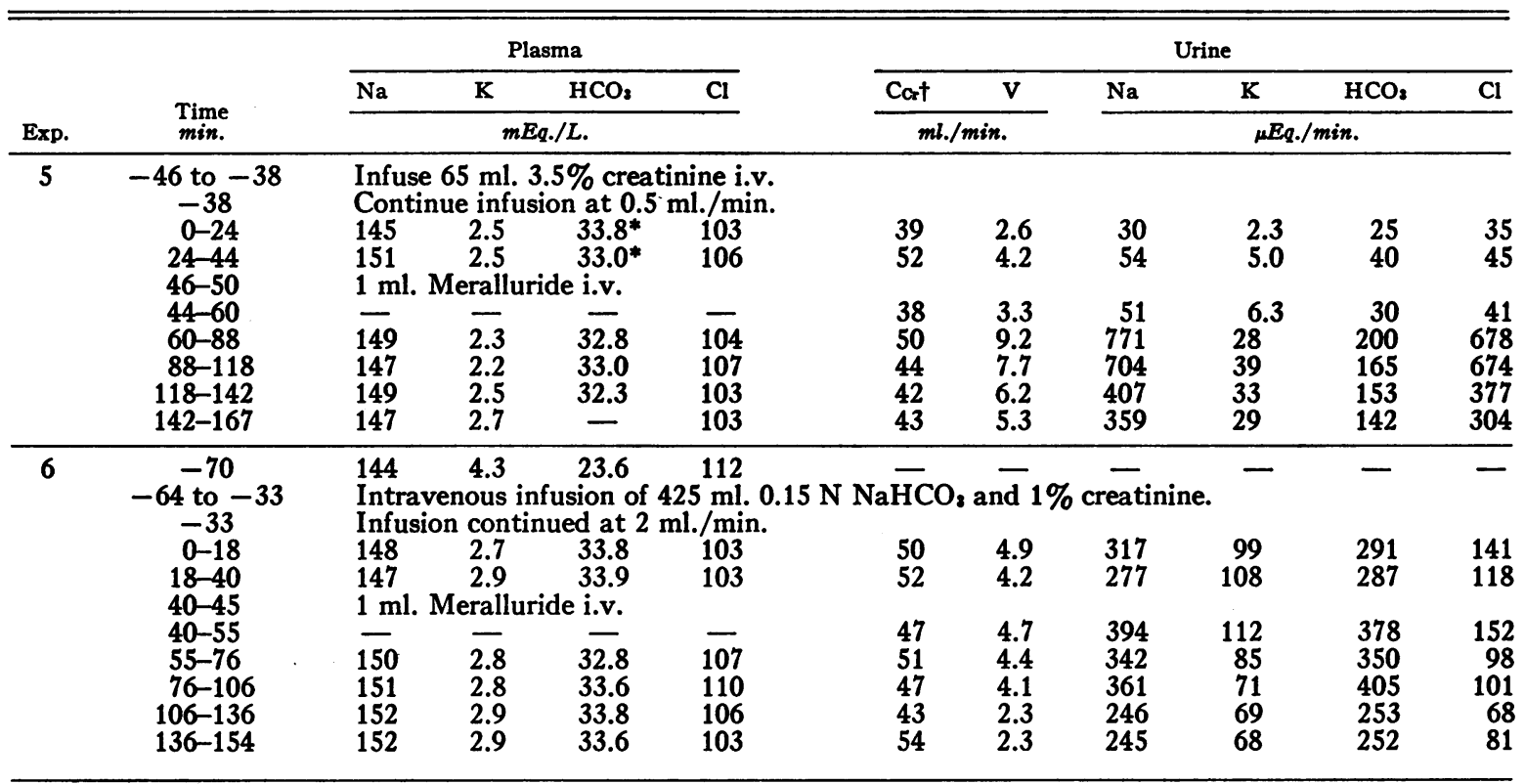

* Blood pH 7.47.

$\dagger$ All urines collected anaerobically without bladder irrigation.

TABLE III

Protocols showing effect of meralluride on electrolyte excretion during alkalosis of potassium depletion and during acute metabolic alkalosis-Dog $W$

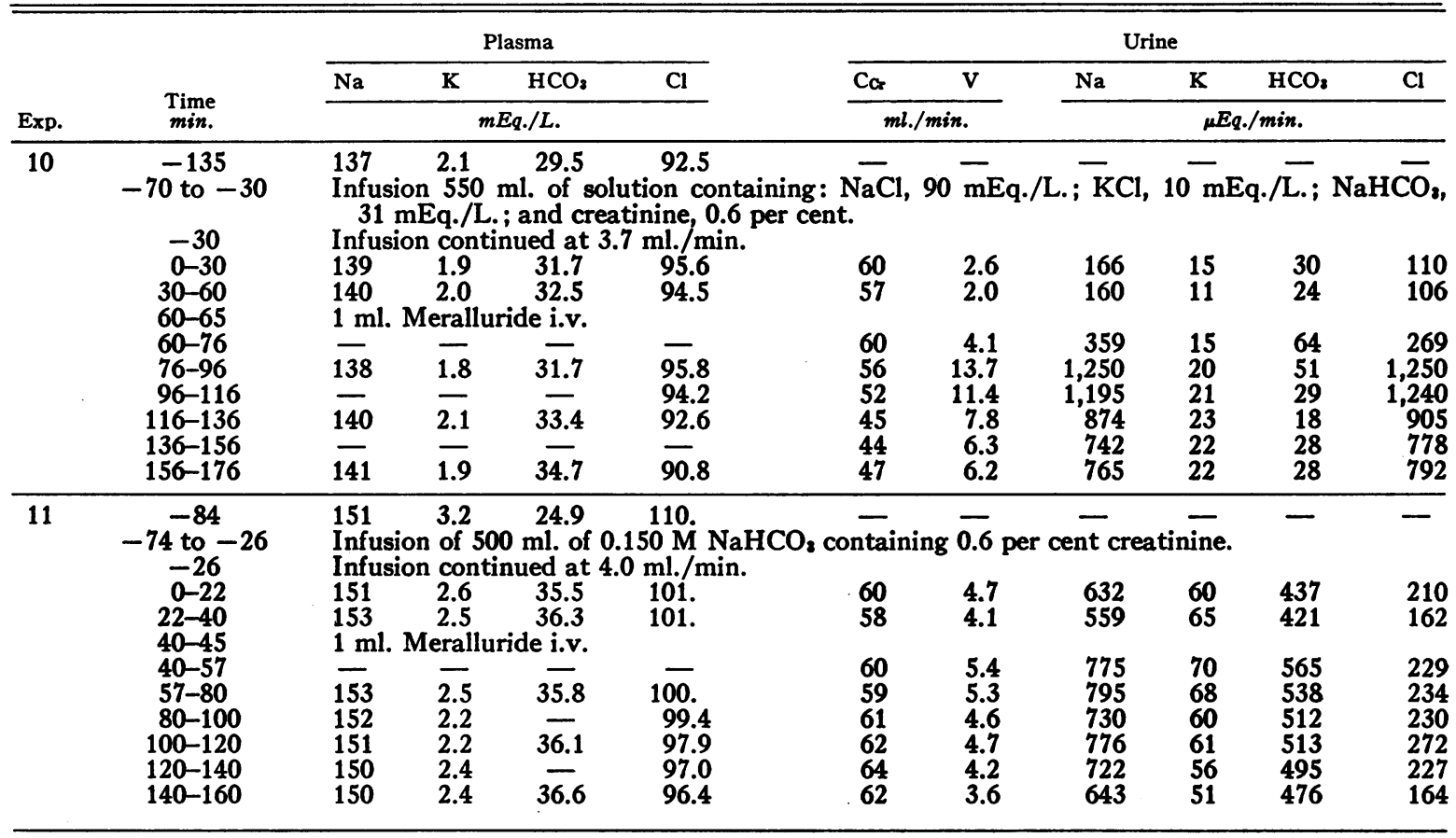




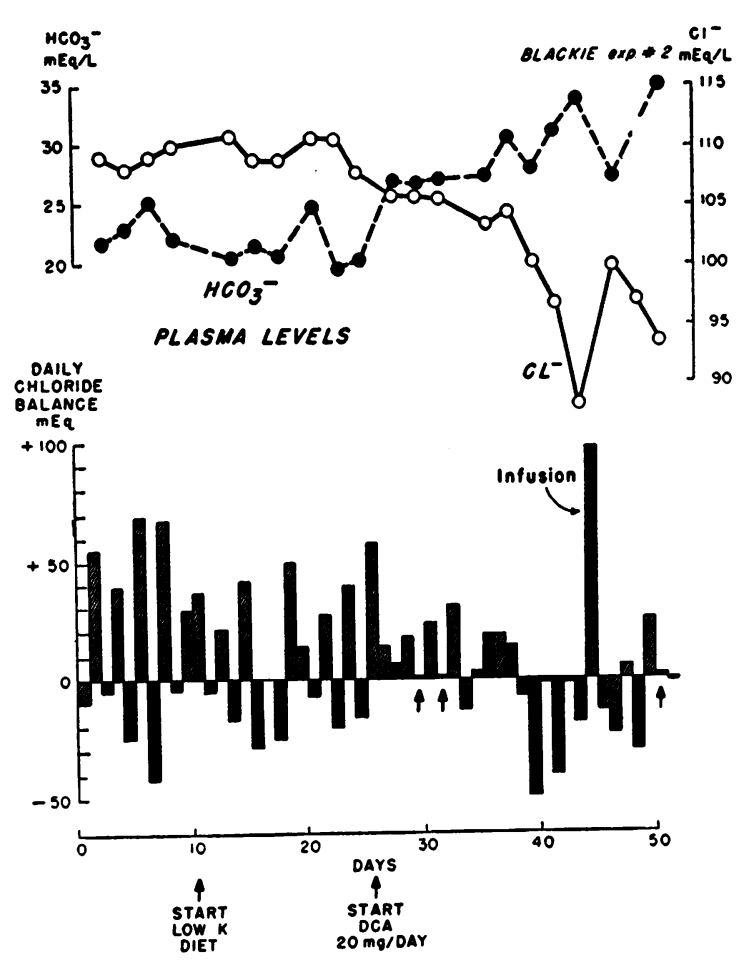

Fig. 3. Effect of Repeated Injections of MeralluRIDE ON Chloride Excretion DURING Development of Alkalosis Due to Potassium Depletion-Dog B

Meralluride was given intravenously on each day indicated by solid black bars or by arrows. The chloride intake was constant at $84 \mathrm{mEq}$. per day until day 38, after which all food was refused except for small amounts on days 49 to 51 . Infusion on day 45 contained $100 \mathrm{mEq}$. $\mathrm{NaCl}$ and $50 \mathrm{mEq} . \mathrm{NaHCO}_{3}$ in one liter, and was given because of inadequate electrolyte intake. The cumulative balance from day 11 to 52 , while on $\mathrm{K}$ poor diet, was : $\mathrm{K},-302 ; \mathrm{Na}$, +625 ; and $\mathrm{Cl},+249 \mathrm{mEq}$.

As depicted by daily balances, the effect of meralluride on chloride excretion on days 49 and 51 is partially masked by coincidental fluctuations in intake. The output on these days was 46 and $23 \mathrm{mEq}$. per day, respectively, while on adjacent control days chloride excretion averaged $2.1 \mathrm{mEq}$. per day.

gested by the daily chloride balance on days 36 and 38 , it is equally possible that an early chloruresis was masked by a compensatory conservation of chloride during the latter part of the 24-hour collection period. Mercury increased chloride excretion more at the start of the study when dietary intake was normal, than towards the end, when all food was refused. At this time the animal lost about $150 \mathrm{mEq}$. of sodium and chloride during one week. A significant decrease in the volume of extracellular fluid and the rate of glomerular fil- tration may be reasonably inferred. Urinary chloride excretion fell to less than $2 \mathrm{mEq}$. per day without mercury, but was increased to between 18 and $50 \mathrm{mEq}$. per day when mercury was administered. An infusion was given on day 45 to restore extracellular volume, and the effect of mercury on subsequent days appeared to have been augmented. This entire experiment illustrates the dependence of mercurial chloruresis on available extracellular fluid. However, despite the severe hypochloremia and the apparent dehydration, the dog did not become refractory to meralluride at any time.

\section{DISCUSSION}

The findings clearly indicate that the chloruretic action of mercurials is dependent on factors other than the amount of chloride filtered at the glomerulus, and are consistent with the concept that tubular $\mathrm{pH}$ may play an important role. Since potassium depletion is characterized by both intracellular acidosis and the excretion of an acid urine, it is not possible to determine definitely whether it is the $\mathrm{pH}$ of the tubular urine or that of the renal cells which conditions the action of the mercurials. Our tentative hypothesis is that the interaction of a cellular constituent and the mercurial may be sensitive to changes in $\mathrm{pH}$. Recently, Benesch and Benesch (26) have reported that reactions between organic mercurials and dithiols are markedly influenced by hydrogen ion concentration. Although there is no direct evidence to implicate cellular dithiols as essential factors in electrolyte transport, the general relationships which have been cited strongly suggest that the $\mathrm{pH}$ of the renal cells may affect mercurial diuresis through such a mechanism.

While the present studies emphasize tubular factors, they in no way rule out the possibility that, under many conditions, the filtered chloride load may be the major determinant of mercurial action. Since these agents act by decreasing the reabsorption of the filtered chloride, it is not surprising that their overall effect may be determined by both glomerular and tubular factors.

It has previously been reported that the administration of either DCA (27) or adrenocorticotrophic hormone (28) decreased the diuretic 
effect of mercurials. However, a subsequent report by Farah (29) failed to demonstrate any antagonism between DCA and mersalyl. In the present studies DCA had no apparent effect on the action of meralluride. The same degree of chloruresis was noted both before and after the administration of the steroid ( $c f$. Exps. 8 and 12). Conversely, DCA did not modify the refractoriness produced by acute metabolic alkalosis.

Many clinical reports have documented the refractoriness to mercurials which appears during alkalosis and which is corrected by the administration of ammonium chloride. However, a survey of the literature has revealed the report of only one patient in whom mercurials retained their effectiveness during severe extracellular alkalosis. Patient S. S. of Schwartz and Wallace (4) responded to meralluride when the serum bicarbonate had risen to $44 \mathrm{mEq}$. per $\mathrm{L}$. and chloride fallen to $82 \mathrm{mEq}$. per L. Although the patient was in negative potassium balance, the authors were unable to implicate this as a factor, since other subjects in their series with comparable potassium deficits did become refractory when they developed mild hypochloremia. Further studies are needed before the role of tubular acidosis can be accurately evaluated as a factor in determining the response of patients to mercurial diuretics.

\section{SUM M ARY}

The diuretic response to organic mercurials was determined in the dog during acute metabolic alkalosis and during chronic alkalosis due to potassium depletion. Acute alkalosis was produced by sodium bicarbonate infusions and was associated with refractoriness to mercurials. When extracellular alkalosis of a similar degree was produced by potassium depletion, the diuretic response to the mercurials was either normal or possibly increased. The results indicate that factors other than the filtered chloride load determine the effectiveness of mercurial diuretics. Since extracellular alkalosis of potassium depletion is accompanied by an intracellular acidosis, it is postulated that increased acidity of the cells of the renal tubule facilitates the interaction between mercurials and cellular components of the electrolyte transport mechanism.

\section{REFERENCES}

1. Keith, N. M., and Whelan, M., A study of the action of ammonium chlorid and organic mercury compounds. J. Clin. Invest., 1926, 3, 149.

2. Ethridge, C. B., Myers, D. W., and Fulton, M. N., Modifying effect of various inorganic salts on the diuretic action of salyrgan. Arch. Int. Med., 1936, 57, 714.

3. Axelrod, D. R., and Pitts, R. F., The relationship of plasma $\mathrm{pH}$ and anion pattern to mercurial diuresis. J. Clin. Invest., 1952, 31, 171.

4. Schwartz, W. B., and Wallace, W. M., Electrolyte equilibrium during mercurial diuresis. J. Clin. Invest., 1951, 30, 1089.

5. Stock, R. J., Mudge, G. H., and Nurnberg, M. J., Congestive heart failure: Variations in electrolyte metabolism with salt restriction and mercurial diuretics. Circulation, 1951, 4, 54.

6. Rice, L., Frieden, J., and Smith, M., Tubular action of mercurial diuretics. Am. J. Physiol., 1953, 175, 47.

7. Goodman, L. S., and Gilman, A., The Pharmacological Basis of Therapeutics, ed. 2, The Macmillan Co., New York, 1955, p. 848.

8. Pitts, R. F., and Duggan, J. J., Studies on diuretics. II. The relationship between glomerular filtration rate, proximal tubular absorption of sodium and diuretic efficacy of mercurials. J. Clin. Invest., 1950, 29, 372.

9. Pitts, R. F., and Sartorius, O. W., Mechanism of action and therapeutic use of diuretics. Pharmacol. Reviews, 1950, 2, 161.

10. Hilton, J. G., Potentiation of diuretic action of mercuhydrin by ammonium chloride. J. Clin. Invest., 1951, 30, 1105 .

11. Mudge, G. H., Unpublished observations.

12. Pitts, R. F., Mechanisms for stabilizing the alkaline reserves of the body. The Harvey Lectures, 19521953, New York, Academic Press, Inc., 1954.

13. Gardner, L. I., MacLachlan, E. A., and Berman, H., Effect of potassium deficiency on carbon dioxide, cation, and phosphate content of muscle with a note on the carbon dioxide content of human muscle. J. Gen. Physiol., 1952, 36, 153.

14. Cooke, R. E., Segar, W. E., Cheek, D. B., Coville, F. E., and Darrow, D. C., The extrarenal correction of alkalosis associated with potassium deficiency. J. Clin. Invest., 1952, 31, 798.

15. Berliner, R. W., Kennedy, T. J., Jr., and Orloff, J., Relationship between acidification of the urine and potassium metabolism. Effect of carbonic anhydrase inhibition on potassium excretion. Am. J. Med., 1951, 11, 274.

16. Roberts, K. E., Randall, H. T., Sanders, H. L., and Hood, M., Effects of potassium on renal tubular reabsorption of bicarbonate. J. Clin. Invest., 1955, 34, 666. 
17. Anderson, H. M., and Mudge, G. H., The effect of potassium on intracellular bicarbonate in slices of kidney cortex. J. Clin. Invest., 1955, 34, 1691.

18. Schales, O., and Schales, S. S., A simple and accurate method for the determination of chloride in biological fluids. J. Biol. Chem., 1941, 140, 879.

19. Ferrebee, J. W., Parker, D., Carnes, W. H., Gerity, M. K., Atchley, D. W., and Loeb, R. F., Certain effects of desoxycorticosterone: the development of "diabetes insipidus" and the replacement of muscle potassium by sodium in normal dogs. Am. J. Physiol., 1941, 135, 230.

20. Smith, S. G., and Lasater, T. E., A diabetes insipiduslike condition produced in dogs by a potassium deficient diet. Proc. Soc. Exper. Biol. \& Med., 1950, 74, 427.

21. Darrow, D. C., Schwartz, R., Iannucci, J. F., and Coville, F., The relation of serum bicarbonate concentration to muscle composition. J. Clin. Invest., 1948, 27, 198.

22. Howell, D. S., and Davis, J. O., Relationship of sodium retention to potassium excretion by the kidney during administration of desoxycorticosterone acetate to dogs. Am. J. Physiol., 1954, 179, 359.
23. Muntwyler, E., Griffin, G. E., Samuelsen, G. S., and Griffith, L. G., The relation of the electrolyte composition of plasma and skeletal muscle. J. Biol. Chem., 1950, 185, 525.

24. Duggan, J. J., and Pitts, R. F., Studies on diuretics. I. The site of action of mercurial diuretics. J. Clin. Invest., 1950, 29, 365.

25. Pitts, R. F., and Lotspeich, W. D., Bicarbonate and the renal regulation of acid base balance. Am. J. Physiol., 1946, 147, 138.

26. Benesch, R., and Benesch, R. E., Reactions of thiols with organic mercury compounds. Arch. Biochem., 1952, 38, 425.

27. Weston, R. E., Escher, D. J. W., Grossman, J., and Leiter, L., Mechanisms contributing to unresponsiveness to mercurial diuretics in congestive failure. J. Clin. Invest., 1952, 31, 901.

28. Axelrod, D. R., and Pitts, R. F., Anoxia as a factor in resistance to mercurial diuretics. Am. J. Physiol., 1952, 169, 350.

29. Farah, A. E., Effects of desoxycorticosterone and adrenocorticotrophic hormone on mercurial diuresis. Proc. Soc. Exper. Biol. \& Med., 1952, 80, 295. 